\title{
Maternal history of childhood sexual abuse and preterm birth: an epidemiologic review CrossMark
}

\author{
Adaeze C. Wosu, Bizu Gelaye* and Michelle A. Williams
}

\begin{abstract}
Background: History of childhood sexual abuse (CSA) is highly prevalent with as many as one in four American women being victims. Exposure to CSA or other early life traumatic experiences has been associated with adverse reproductive and pregnancy outcomes. However, the effects of CSA on preterm delivery (PTB), a leading cause of neonatal mortality, remain poorly understood. The objectives of this review are (i) to synthesize the available research investigating the relationship between maternal history of childhood sexual abuse (CSA) and preterm delivery (PTB); (ii) to provide suggestions for improving future research on this topic; and (iii) to highlight implications for clinical practice and public health.
\end{abstract}

Methods: Relevant articles were identified through searches of four electronic databases (PubMed, CINAHL, Web of Science Core Collection and BIOSIS Online) for studies published before March 2014, as well as through reviewing references of published articles.

Results: A total of six studies published from 1992 to 2010 were included in this review. Overall, findings were inconsistent. Three studies reported statistically significant associations of CSA with PTB ( $<37$ weeks gestation) or shorter mean gestational age at birth. Women with a history of CSA had 2.6 to 4.8-fold increased odds of PTB as compared with women without a history of CSA. Three other studies did not observe statistically significant differences in rates of PTB or mean gestational age at birth in relation to a history of CSA.

Conclusions: Available evidence on this topic is sparse and inconsistent, and limited by a number of methodological challenges. Given the ubiquity of CSA, as well as the clinical and public health significance of PTB, more rigorously designed epidemiologic studies on the association between CSA and PTB are warranted.

\section{Introduction}

\section{Definitions, prevalence and correlates of CSA}

Childhood sexual abuse (CSA) is a major public health problem with serious immediate and long-term health consequences [1-3]. Although significant variation exists in its definition, CSA is generally recognized as the involvement of a child in sexual activity that is not developmentally appropriate, that he or she does not fully comprehend or is unable to give consent to, by an individual who by age or development is in a relationship of responsibility, trust or power to the child. CSA may involve use of manipulation, coercion, threats or violence to engage a child in sexual activity [4].

Generally, CSA is characterized into three broad categories: (a) non-contact sexual abuse (e.g. exhibitionism,

\footnotetext{
* Correspondence: bgelaye@hsph.harvard.edu

Department of Epidemiology, Harvard T.H. Chan School of Public Health, 677 Huntington Ave, K505F, Boston, MA 02115, USA
}

indecent exposure, sexual harassment or voyeurism); (b) contact sexual abuse without penetration (e.g. nongenital fondling, kissing, or genital touching); and (c) contact sexual abuse with penetration (e.g. anal, oral, or vaginal intercourse) is recognized as the most severe. In addition, CSA may be characterized in terms of frequency, duration, age of onset of abuse, and relationship of the victim to the perpetrator [5].

Recent prevalence estimates of CSA, summarized in meta-analyses and multi-country studies confirm high global prevalence, with markedly higher prevalence among girls as compared with boys; see Table 1 for a summary of CSA estimates from recent studies [5-10]. Briefly, in their study of student and community samples from 22 countries, Pereda et al. reported that the average prevalence of CSA was $19.7 \%$ for girls and $7.9 \%$ for boys [10]. These figures were corroborated by other investigators who reported global CSA prevalence estimates of $7.6 \%$ for boys 
Table 1 Summary of global prevalence of CSA

\begin{tabular}{|c|c|c|c|c|c|}
\hline \multirow[t]{2}{*}{ First author (year) } & \multirow[t]{2}{*}{ Definition of CSA } & \multirow[t]{2}{*}{ Studies included } & \multicolumn{3}{|c|}{ Prevalence estimates } \\
\hline & & & Overall & Boys & Girls \\
\hline Andrews (2004) [5] & $\begin{array}{l}\text { Contact and non-contact (age varied } \\
\text { across studies; upper limit was } 18 \text { years) }\end{array}$ & 513 articles or reports & $\begin{array}{l}\text { Range } \\
3.8-67.7 \%\end{array}$ & $\begin{array}{l}\text { Range } \\
3.8-35 \%\end{array}$ & $\begin{array}{l}\text { Range } \\
8.4-67.7 \%\end{array}$ \\
\hline $\begin{array}{l}\text { WHO } \\
\text { multi-country study } \\
\text { (2005) [9] }\end{array}$ & $\begin{array}{l}\text { Unwanted or forced sexual activity } \\
\text { before age } 15 \text { years }\end{array}$ & $\begin{array}{l}24,058 \text { individuals in } 15 \text { sites in } \\
10 \text { countries around the world }\end{array}$ & --- & --- & $\begin{array}{l}\text { Range } \\
1-21 \%\end{array}$ \\
\hline Pereda (2009a) [6] & $\begin{array}{l}\text { Contact and non-contact (age varied } \\
\text { across studies; upper limit was } 18 \text { years) }\end{array}$ & $\begin{array}{l}38 \text { independent articles } \\
\text { representing } 21 \text { countries }\end{array}$ & $\begin{array}{l}\text { Range } \\
0-60 \%\end{array}$ & $\begin{array}{l}\text { Range } \\
0-60 \%\end{array}$ & $\begin{array}{l}\text { Range } \\
0-53 \%\end{array}$ \\
\hline Pereda (2009b) [10] & $\begin{array}{l}\text { Contact and non-contact (age varied } \\
\text { across studies; upper limit was } 17 \text { years) }\end{array}$ & 65 articles, covering 24 countries & $\mathrm{N} / \mathrm{A}$ & $\begin{array}{l}7.9 \%(95 \% \\
\mathrm{Cl} 6.0-10.3 \%)\end{array}$ & $\begin{array}{l}19.7 \%(95 \% \\
\text { Cl } 16.7-23.0 \%)\end{array}$ \\
\hline $\begin{array}{l}\text { Stoltenborgh } \\
\text { (2011) [7] }\end{array}$ & $\begin{array}{l}\text { Contact and non-contact (age varied } \\
\text { across studies; upper limit was } 18 \text { years) }\end{array}$ & $\begin{array}{l}331 \text { independent samples from } \\
217 \text { publications }\end{array}$ & $\begin{array}{l}11.8 \%(95 \% \\
C l 10.0-13.8 \%)\end{array}$ & $\begin{array}{l}7.6 \%(95 \% \\
\mathrm{Cl} 6.6-8.8 \%)\end{array}$ & $\begin{array}{l}18 \%(95 \% \\
\mathrm{Cl} 16.4-19.7 \%)\end{array}$ \\
\hline Barth (2013) [8] & $\begin{array}{l}\text { Contact and non-contact (age varied } \\
\text { across studies; upper limit was } 19 \text { years) }\end{array}$ & 55 studies from 22 countries & $\begin{array}{l}\text { Range } \\
3-31 \%\end{array}$ & $\begin{array}{l}\text { Range } \\
3-17 \%\end{array}$ & $\begin{array}{l}\text { Range } \\
8-31 \%\end{array}$ \\
\hline
\end{tabular}

Abbreviations: CSA Childhood sexual abuse, WHO World Health Organization

and $18 \%$ for girls [7]. It is important to note that CSA rarely occurs as a solitary episode but appears to consist of continued sexual victimization and maltreatment. CSA typically co-occurs with one or more types of childhood maltreatment (i.e., child neglect, physical abuse, and emotional abuse) $[5,11]$.

The prevalence of CSA in hospital and clinic based studies of pregnant women, primarily from high-income countries, range from 3.2 to $32.2 \%$ [12-22]. As with studies conducted among non-pregnant individuals, much of the heterogeneity in CSA prevalence estimates are attributable to differences in operational definitions of CSA, differences in study setting, study design, sampling methods and sample size. For example, Sørbø et al. observed CSA prevalence of $7 \%$ using one question to screen for CSA: "have you been forced to have sexual intercourse (as a child, under 18 years old)?" [13], whilst Yampolsky et al. observed a prevalence of $32.2 \%$ using the 14-item Childhood Sexual Assaults Scale [12].

\section{CSA and health outcomes}

The relation of CSA with a range of health outcomes has been well documented among men and women. Investigators have reported strong associations of CSA with psychiatric disorders including post-traumatic stress disorder (PTSD) [2], depression [23], suicidal behavior [1, 2], and substance abuse [24, 25]. Investigators have also described dose-response relationships between CSA severity and worsening psychiatric health. For example, the number of suicide attempts was shown to increase with frequency of CSA $(\beta=0.56, \mathrm{SE}=0.23, p<0.05)$ and with use of force during CSA $(\beta=1.13, \mathrm{SE}=0.57, p<0.05)$ among men [26]. Similarly, CSA involving intercourse was found to be more strongly associated with psychiatric and substance use disorders as compared with CSA that did not involve intercourse [24].
CSA is linked to increased odds of a host of adverse reproductive characteristics in women including early age at menarche [27, 28] and adolescent pregnancy [29]. Among pregnant women, history of CSA has been associated with psychiatric disorders [30,31], physical, sexual, or emotional abuse during pregnancy [30], and lifestyle risk behaviors such as cigarette smoking [30, 32], all of which may endanger the health of both mother and her developing fetus.

\section{Definition, prevalence and correlates of preterm birth}

Preterm birth (PTB), defined as birth prior to the completion of 37 weeks gestation [33], is the leading cause of neonatal mortality [34]. Globally, approximately 15 million infants (i.e., $10 \%$ of all births) are delivered preterm and about 1 million of these infants die as a result of their prematurity [34]. Maternal risk factors associated with PTB include cigarette smoking [35], previous preterm birth [36], infection [37], preeclampsia [38], obesity [39], psychiatric disorders [40, 41], psychotropic medication use [42] and exposure to intimate partner violence [43].

Although the majority of preterm births occur in low and middle income countries [34], PTB remains a significant problem in developed countries. In the United States, 1 in 8 infants is born preterm, although PTB rates seem to be on the decline (from $12.8 \%$ in 2006 to $11.6 \%$ of all births in 2012) [33, 44]. Preterm birth is associated with enormous social and economic burdens as outlined in a report from the Institute of Medicine [45]. The report estimated the maternal birth costs, early intervention services, four disabling conditions occurring from preterm birth, and lost household and labor market productivity costs related to PTB to be at least $\$ 26.2$ billion (or $\$ 51,600$ per infant born preterm) in 2005 [45]. Compared with term infants, preterm infants are at an increased risk for immediate and long-term health problems 
$[46,47]$. Notably, an accumulating literature now documents increased risk of later-life cardiovascular-related conditions for mothers of preterm infants [48-50].

Despite its high prevalence, the etiology of PTB is not well understood [45]. However, some investigators suggest that early life stress, such as CSA, may be associated with PTB [51]. Given the importance of CSA and PTB as two public health conditions with major consequences for maternal and child health, our objectives in conducting this review are: (i) to synthesize the limited available research investigating the relationship between maternal history of childhood sexual abuse (CSA) and preterm birth (PTB); (ii) to provide suggestions for improving future research on this topic; and (iii) to highlight implications for clinical practice and public health.

\section{Methods}

\section{Search strategy}

Relevant studies published before March 2014 were identified from four online databases (PubMed, Cumulative Index of Nursing and Allied Health Literature (CINAHL), Web of Science Core Collection and BIOSIS Online). A full list of search terms used can be found in Additional file 1: Table S1. We also reviewed references of retrieved publications to identify other potentially relevant articles reporting on the association between CSA and PTB.

\section{Selection criteria}

The exposure of interest was maternal exposure to CSA, and the outcome of interest was preterm birth or gestational age at birth. To be included, studies had to: (1) define CSA as occurring sometime before age 18 years; (2) report quantitative associations between CSA and PTB or gestational age at birth; (3) be observational studies (cross-sectional, prospective cohort, retrospective cohort, and case-control studies); and (4) be full-length papers (conference abstracts, case studies, gray literature, editorials were excluded).

\section{Results}

The electronic database search identified 2,207 titles, of which 1955 were duplicates or rejected upon title review. The abstracts of the remaining unique 252 articles were read. Of these, 34 were selected for full-text screening (Fig. 1 summarizes the selection and screening process). Six full-length papers met the inclusion criteria and were included in this review (Table 2-papers in table are arranged by year of publication). The studies were published from 1992 to 2010 and in English. Four of the studies were from the United States while the other two were from Norway and Germany, respectively. Three studies used a prospective cohort design, two were retrospective cohort studies, and one was a case-control study. Findings were inconsistent, with only three studies reporting statistically significant positive associations of CSA with PTB or shorter mean gestational age at birth. In the sections below, we describe each study.

Steven-Simons and colleagues analyzed data for 127 women who were $<19$ years old at the time of conception of pregnancy. History of current or prior physical or sexual abuse was obtained through interviews and was defined as answering "yes" to the question "Have you ever been physically or sexually abused?" or other related

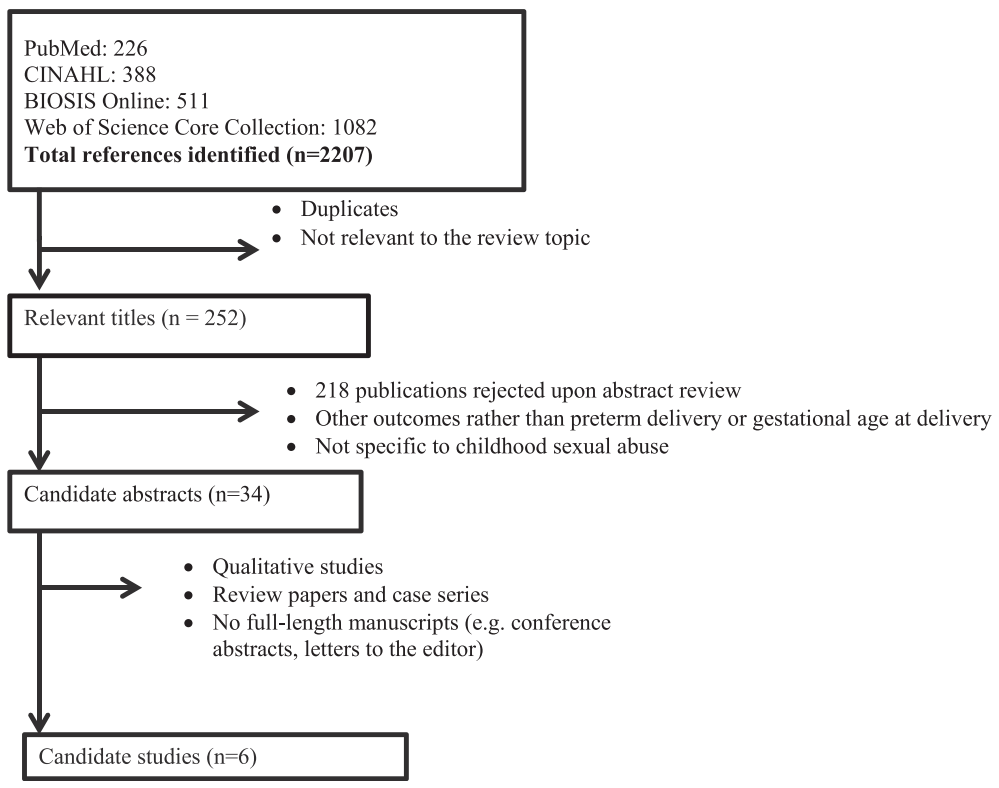

Fig. 1 Flowchart showing selection of articles reporting on the relationship between CSA and preterm birth 
Table 2 Summary of original studies examining the association of maternal history of CSA with preterm birth or gestational age at birth

\begin{tabular}{|c|c|c|c|c|c|c|c|}
\hline First author (year) & Country & Study design & Sample size & Recruitment & CSA definition & $\begin{array}{l}\text { PTB } \\
\text { definition }\end{array}$ & CSA and PTB findings \\
\hline $\begin{array}{l}\text { Jacobs } \\
(1992)[56]\end{array}$ & $\begin{array}{l}\text { United } \\
\text { States }\end{array}$ & Retrospective & $\begin{array}{l}15 \text { CSA-exposed, } 13 \\
\text { controls }\end{array}$ & $\begin{array}{l}\text { CSA-exposed women recruited from } \\
\text { survivors' group, mental health center } \\
\text { and through therapists; controls } \\
\text { recruited from evening psychology } \\
\text { class taught in the community }\end{array}$ & CSA definition not specified & $\begin{array}{l}\text { Mean } \\
\text { gestational } \\
\text { age at birth }\end{array}$ & $\begin{array}{l}\text { No significant correlation between being a } \\
\text { victim of CSA and gestational age at birth in } \\
\text { the entire sample }(r=0.12, p>0.05) \text {. } \\
\text { However, the authors reported a positive } \\
\text { correlation between gestational age at birth } \\
\text { and maternal history of being sexually } \\
\text { touched as a child }(r=0.34, p<0.05) \text {. }\end{array}$ \\
\hline $\begin{array}{l}\text { Stevens-Simon } \\
\text { (1994) [52] }\end{array}$ & $\begin{array}{l}\text { United } \\
\text { States }\end{array}$ & $\begin{array}{l}\text { Prospective } \\
\text { cohort }\end{array}$ & 127 women & $\begin{array}{l}\text { Participants in the Rochester Study of } \\
\text { Adolescent Pregnancy }\end{array}$ & $\begin{array}{l}\text { Physical or sexual abuse } \\
\text { ( }<19 \text { years })\end{array}$ & $\begin{array}{l}<37 \text { weeks } \\
\text { gestation }\end{array}$ & $\begin{array}{l}\text { CSA-exposed women had shorter mean } \\
\text { gestational lengths ( } 38.0 \pm 3.4 \text { weeks) } \\
\text { compared with non-exposed }(39.1 \pm \\
1.7 \text { weeks, } p \leq 0.05) \text {. PTB more common } \\
\text { among exposed women }(19.1 \% \text { vs. } 4.7 \% \text {, } \\
p \leq 0.05 \text {; OR }=4.76,95 \% \text { Cl: } 1.34,16.89)\end{array}$ \\
\hline $\begin{array}{l}\text { Benedict } \\
\text { (1999) [55] }\end{array}$ & $\begin{array}{l}\text { United } \\
\text { States }\end{array}$ & $\begin{array}{l}\text { Prospective } \\
\text { cohort }\end{array}$ & 357 women & $\begin{array}{l}\text { Prenatal clinics in a large university- } \\
\text { based hospital; women interviewed at } \\
28-32 \text { weeks gestation }\end{array}$ & $\begin{array}{l}\geq 1 \text { non-consensual and non- } \\
\text { experimental contact or non- } \\
\text { contact sexual episode } \\
\text { ( }<18 \text { years) by a perpetrator } \\
\text { who was } \geq 5 \text { years older than } \\
\text { victim }\end{array}$ & $\begin{array}{l}<37 \text { weeks } \\
\text { gestation }\end{array}$ & $\begin{array}{l}\text { No statistically significant association } \\
\text { between CSA and gestational age at birth }\end{array}$ \\
\hline $\begin{array}{l}\text { Grimstad } \\
\text { (1999) [32] }\end{array}$ & Norway & Case-control & $\begin{array}{l}82 \text { women with } \\
\text { low birth weight } \\
\text { infants, } 91 \text { women } \\
\text { with normal birth } \\
\text { weight infants }\end{array}$ & $\begin{array}{l}\text { Department of Obstetrics, the } \\
\text { University Hospital of Trondheim }\end{array}$ & $\begin{array}{l}\text { Adverse sexual experiences } \\
(<18 \text { years })\end{array}$ & $\begin{array}{l}\text { Not } \\
\text { defined }\end{array}$ & $\begin{array}{l}\text { PTB prevalence similar for abused and non- } \\
\text { abused women ( } 36 \% \text { vs. } 32 \%, p=0.68)\end{array}$ \\
\hline $\begin{array}{l}\text { Noll } \\
(2007)[53]\end{array}$ & $\begin{array}{l}\text { United } \\
\text { States }\end{array}$ & $\begin{array}{l}\text { Prospective } \\
\text { cohort }\end{array}$ & $\begin{array}{l}40 \text { CSA-exposed, } 31 \\
\text { controls }\end{array}$ & $\begin{array}{l}\text { CSA-exposed girls were referred by } \\
\text { CPS; unexposed girls were recruited } \\
\text { through community advertisements }\end{array}$ & $\begin{array}{l}\text { Substantiated contact sexual } \\
\text { abuse perpetuated by a family } \\
\text { member (between } 6 \text { and } \\
16 \text { years) }\end{array}$ & $\begin{array}{l}<37 \text { weeks } \\
\text { gestation }\end{array}$ & $\begin{array}{l}\text { PTB risk increased among women with CSA } \\
\text { vs. non-abused women ( } 21 \% \text { vs. } 11 \% \text {; } \\
\text { OR }=2.80, p<0.05 \text { ) }\end{array}$ \\
\hline $\begin{array}{l}\text { Leeners } \\
\text { (2010) [54] }\end{array}$ & Germany & $\begin{array}{l}\text { Retrospective } \\
\text { cohort }\end{array}$ & $\begin{array}{l}85 \text { CSA-exposed, } \\
170 \text { controls }\end{array}$ & $\begin{array}{l}\text { CSA-exposed women recruited } \\
\text { through sexual abuse survivor centers } \\
\text { in large cities; unexposed women } \\
\text { were recruited through local } \\
\text { kindergartens }\end{array}$ & $\begin{array}{l}\text { Contact and non-contact } \\
\text { sexual abuse ( }<18 \text { years) }\end{array}$ & $\begin{array}{l}<37 \text { weeks } \\
\text { gestation }\end{array}$ & $\begin{array}{l}\text { PTB risk increased among women with CSA } \\
\text { history vs non-abused women ( } 18.8 \% \text { vs. } \\
8.2 \%, p=0.02 ; \mathrm{OR}=2.58,95 \% \text { Cl: } 1.19-5.59)\end{array}$ \\
\hline
\end{tabular}

Abbreviations: CPS Child protective services, CSA Childhood sexual abuse, PTB Preterm birth 
questions. Overall, 42 women (33 \%) reported exposure to childhood physical or sexual abuse. The authors noted that abused women delivered approximately 1 week earlier, on average, as compared with non-abused women (mean gestational age at birth: $38.0 \pm 3.4$ vs. $39.1 \pm$ 1.7 weeks, $p \leq 0.05)$. Also, the frequency of PTB was higher among abused women as compared with nonabused women (19.1\% vs. $4.7 \%, p<0.05$; unadjusted $\mathrm{OR}=4.76,95 \% \mathrm{CI}: 1.34,16.89)$. However, the authors reported that when controlling for maternal stress, depression, social support, and substance abuse, the association between abuse and gestational age at birth was not statistically significant (quantitative summary not reported) [52]. It is possible that some of these factors may be indirect effects of CSA. A major strength of this study is the use of various methods to substantiate infant gestational age at birth. However, inference from this study is limited by the lack of differentiation between childhood sexual and physical abuse, and lack of adjustment for age. Since the sample ranged from 12 to 18 years old, youngest members of the sample may have been at particularly high risk for preterm birth.

In a prospective cohort study of 40 women with CSA history and 31 without a history of CSA, Noll and colleagues reported that the odds of PTB was elevated among women with a history of CSA as compared with those who had no such history of abuse ( $21 \%$ vs. $11 \%$; adjusted $\mathrm{OR}=2.80, p<0.05$, adjusted for minority status and sibling number). Prenatal alcohol use, but not maternal cortisol concentrations, mediated this relationship [53]. Important strengths of this study included the prospective study design, and clear definition of CSA (i.e., contact sexual abuse by a family member that occurred while participants were between the ages of 6-16 years, and was reported to Child Protection Services), and major improvements in statistical analyses over preceding studies.

Recently, Leeners et al. conducted a retrospective cohort study of 85 women with CSA history who were attending sexual abuse support centers and 170 women without a history of CSA. CSA was defined as contact or non-contact sexual abuse prior to age 18 years and delivery information was ascertained from medical records. The investigators found that abused women were more likely to deliver preterm as compared with non-abused women $(18.8 \%$ vs. $8.2 \%, p=0.02$; unadjusted $\mathrm{OR}=2.58$, 95 \% CI: 1.19, 5.59) [54].

In contrast to the studies described above, three other studies did not observe significant associations of CSA with PTB or mean gestational age at birth. In a casecontrol study conducted in Norway, Grimstad and colleagues analyzed data for 82 women who delivered low birth weight $(<2500 \mathrm{~g})$ infants, and 91 women with normal birth weight ( $\geq 2500 \mathrm{~g})$ infants. A positive history of CSA was determined on the basis of participants' response to a single question as to whether they had negative sexual experiences prior to age 18 years. The authors did not observe a significant difference in the prevalence of preterm birth (definition not specified) among women with CSA history (36 \%) and women with no CSA history (32\%, $p=0.68)$ [32].

Benedict and colleagues conducted a prospective cohort study to examine the association of CSA with depressive symptomatology, negative life events, and selected pregnancy outcomes, including gestational age at birth among 357 women aged $\geq 18$ years. CSA was defined as $\geq 1$ episode of non-consensual and non-experimental contact or non-contact sexual abuse prior to 18 years by a perpetrator $\geq 5$ years older than the victim. However, if force was used, women were considered as CSA-exposed regardless of age difference with perpetrator. Thirty-seven percent of participants reported exposure to CSA and prevalence of PTB in the entire sample was $13 \%$. The authors reported no significant association of CSA with mean number of gestational weeks at birth or PTB observed (no quantitative summary was shown) [55]. Finally, in a small $(N=28)$ retrospective cohort study, Jacobs reported no statistically significant association between being a victim of CSA and PTB or gestational age at birth. However, the authors reported a positive correlation between gestational age at birth and maternal history of being sexually touched as a child $(\mathrm{r}=0.34, p<0.05)$. Due to a number of methodological challenges, one being an extremely small sample size, findings from this study, particularly those on the CSA sub-category of being sexually touched as a child, should be interpreted with caution [56].

\section{Limitations of available evidence}

These studies on the association of CSA with PTB or gestational age at birth had some common limitations. First, the majority of studies were based on convenience samples with relatively small sizes (range from 28 to 357 women), which limited statistical power and hindered inferences that could be made from the studies. Second, there was significant heterogeneity across studies with regard to the definition of CSA, i.e., level of contact considered, mode of ascertainment of CSA history, and the maximum cutoff age for CSA (range from 16 to 19 years of age). These differences in the operational definition of CSA may have contributed to variations in CSA prevalence and observed associations of CSA with PTB and gestational age at birth. Third, the mode of ascertainment of PTB or gestational age at birth varied, from maternal self-report [56], to extraction from medical records [53-55], to ultrasound dating [32, 52]. Fourth, most of the studies were not specifically designed to determine the extent to which, if at all, maternal history of exposure to CSA is associated with PTB risk, rather they 
were secondary analyses of data collected for other purposes. Thus, most analyses of the CSA-PTB relationship were preliminary and did not adequately account for important confounding factors, mediators and modifiers such as maternal preconception and antepartum exposures to cigarette smoking, mood and anxiety symptomatology, and stressors such as intimate partner violence and sexual abuse in adulthood. Fifth, CSA histories were assessed retrospectively for the majority of studies, and so may have been subject to reporting errors. Lastly, all studies were from high-income countries (US, Norway and Germany). Thus, results may not be generalizable to women in low and middle-income countries.

\section{Hypothesized biological mechanisms}

Pathophysiological mechanisms that may account for observed associations of CSA exposure histories with PTB are not well known. However, investigators have suggested that CSA, an early life stressor, contributes to psychological stress and promotes dysregulation of the hypothalamicpituitary-adrenal (HPA) axis, one of two major neuroendocrine pathways activated in stress response [51]. HPA axis activation begins with discharge of corticotrophin-releasing hormone $(\mathrm{CRH})$ from the hypothalamus, which then triggers the secretion of adrenocorticotropic hormone (ACTH) by the pituitary and the subsequent release of cortisol by the adrenal cortex [57]. CRH is also found in other sites including the placenta, ovaries, and adrenal glands $[57,58]$. During pregnancy, maternal CRH concentrations rise due to increased CRH synthesis in the fetus, placenta and uterine lining, resulting in increases in maternal $\mathrm{ACTH}$ and cortisol concentrations [58].

In their review paper, Horan and colleagues propose that the trauma, stress and fear associated with CSA may stimulate enhanced CRH gene expression and chronic overproduction of $\mathrm{CRH}$ in the brain, making a woman susceptible to elevated placental $\mathrm{CRH}$ gene expression during pregnancy and consequently, increased risk of PTB [51]. This thesis is supported by animal studies that showed that infusion of CRH initiated early labor [59] and a Type I CRH receptor antagonist delayed parturition [60]. In humans, elevated third trimester placental CRH concentrations have been associated with increased risks of spontaneous PTB and/or fetal growth restriction [61-63]. These studies support CRH's role in labor initiation, particularly its function as a placental clock that may regulate the length of human gestation [64]. CSA may also increase risk for PTB through mediators such as psychiatric disorders [40], obesity [25], and lifestyle factors such as alcohol use [53], and cigarette smoking [65], which have been shown to be associated with CSA [24, 30] and with increased risk for PTB [45]. As observed by Noll and colleagues (in one of the studies included in this review) maternal prenatal alcohol use was a mediator of the CSA-PTB relationship [53].

\section{Discussion}

CSA is a highly prevalent early life stressor with wide-ranging immediate and long-term biological and psychological sequelae [5]. Among pregnant women, some investigators have documented associations of CSA history with cigarette smoking [30,32], psychiatric disorders [31], and abuse during pregnancy [30], known risk factors for preterm birth. Preterm birth occurs in $10 \%$ of all births globally, and has tremendous medical, economic, and health implications for mother, infant, and society at-large [45]. Available evidence suggest that maternal history of early life adversity may play a role in PTB [51]. However, only a limited number of studies have empirically examined associations of CSA, a common stressor in the lives of young girls and women, with PTB.

As reported in this review of the six published studies on the topic to date, only three studies observed statistically significant associations of CSA with PTB or shorter mean gestational age at birth [52-54]. Three other studies did not observe substantial or statistically significant associations [32, 55, 56], although one study reported higher prevalence of PTB for women with a history of CSA (36 \%) compared to women with no such history (32\%) [32] and another study observed an increased gestational age at birth with one sub-category of women with a history of CSA [56]. Inferences from the majority of available studies on the CSA-PTB relationship are hindered by small sample sizes, and incomplete control of confounding factors. Of note, these studies did not adequately distinguish the effects of CSA from the effects of other forms of childhood maltreatment or trauma, or later-life abuse. CSA and PTB are common and have significant clinical and developmental consequences for mothers and children. There is need for longitudinal and rigorously designed studies to improve understanding of the CSA-PTB relationship. Here, we offer some considerations for improving future studies on this topic:

1. The use of detailed CSA questionnaires (e.g., The Childhood Trauma Questionnaire and The Sexual and Physical Abuse Questionnaire) in future CSA-PTB studies would allow for more uniform exposure collection efforts and capture of a wide range of CSA severities to enable nuanced analyses and interpretation of findings.

2. Studies should distinguish between sub-categories of preterm birth (i.e., extremely preterm, very preterm, and moderate to late preterm) to add greater specificity to the existing literature and further inform the development of clinical risk stratification and risk management protocols. 
3. Longitudinal studies incorporating the use of biological samples may facilitate understanding of biological mechanisms and identify important mediators and modifiers of the CSA-PTB relationship.

4. Study design and analytical approaches to account for confounders and potential mediators (e.g., other forms of child maltreatment and trauma, adult traumatic experiences, socioeconomic status, prenatal cigarette smoking, illicit drug or alcohol use) will improve validity and precision of measured CSA-PTB associations.

5. Efforts should be made to quantify the contribution of CSA to PTB incidence in middle and low-income countries, particularly those countries with high prevalence of CSA. Such efforts would expand current knowledge and may be informative for PTB prevention in these settings.

6. Prevention of both CSA and PTB requires a multisectorial response. Prevention and risk management efforts should engage individuals from health services, educational, advocacy, institutions, with better recognition of the social, cultural and environmental milieu within which CSA and PTB occur.

\section{Conclusions}

\section{Clinical and public health implications}

In spite of the great strides that have been made towards elucidating the medical, environmental, psychosocial and genetic risk factors of PTB [45], this review underscores that much remains to be done to fully understand the contribution of CSA to PTB. Given (1) the high prevalence of history of CSA among women, (2) the relationships between CSA and adverse reproductive characteristics and risk behaviors during pregnancy, (3) the accumulating evidence linking PTB to adverse long-term maternal and child health outcomes, and (4) the observed associations of maternal history of CSA with PTB, identifying women with a history of CSA, and providing them with increased attention and care during pregnancy may be one important strategy for PTB prevention. Finally, women with a history of CSA may also benefit from additional education and intervention (e.g., psychosocial support) targeted at modifying health risk behaviors for better maternal and infant health outcomes.

\section{Additional file}

Additional file 1: Table S1. Search terms used to identify relevant publications. (DOCX $14 \mathrm{~kb}$ )

\section{Abbreviations}

ACTH: Adrenocorticotropic hormone; Cl: Confidence interval; CINAHL: Cumulative index to nursing and allied health literature; $\mathrm{CRH}$ : Corticotrophin-releasing hormone; CSA: Childhood sexual abuse;
HPA: Hypothalamic-pituitary-adrenal; OR: Odds ratio; PTB: Preterm birth; US: United States; WHO: World Health Organization.

\section{Competing interests}

The authors declare that they have no competing interests.

\section{Authors' contributions}

ACW performed the literature search and screening of articles. ACW, BG, and MAW participated in the evaluation of relevant articles, and writing of the manuscript. All authors have read and approved the final manuscript.

\section{Acknowledgments}

This research was supported by awards from the National Institutes of Health, the Eunice Kennedy Shriver Institute of Child Health and Human Development (5R01-HD-059827 and 1R01-HD-059835), and National Institute of Minority Health and Health Disparities (T37-MD-001449). The National Institutes of Health had no further role in the study design, in the collection, analysis and interpretation of data, in the writing of the report, or in the decision to submit the paper for publication.

Received: 23 February 2015 Accepted: 4 August 2015

Published online: 15 August 2015

\section{References}

1. Molnar B, Berkman L, Buka S. Psychopathology, childhood sexual abuse and other childhood adversities: relative links to subsequent suicidal behaviour in the US. Psychol Med. 2001;31(6):965-77.

2. Molnar B, Buka S, Kessler R. Child sexual abuse and subsequent psychopathology: results from the National Comorbidity Survey. Am J Public Health. 2001;91(5):753-60.

3. Lindert J, von Ehrenstein OS, Grashow R, Gal G, Braehler E, Weisskopf MG. Sexual and physical abuse in childhood is associated with depression and anxiety over the life course: systematic review and meta-analysis. Int J Public Health. 2014;59(2):359-72.

4. World Health Organization. Guidelines for Medico-Legal Care for Victims of Sexual Violence. Geneva: World Health Organization; 2003.

5. Andrews G, Corry J, Slade T, Issakidis C, Swanston H. Child Sexual Abuse. In: Ezzati M, Lopez A, Rodgers A, Murray C, editors. Comparative Quantification of Health Risks : Global and Regional Burden of Disease Atrributable to Selected Major Risk Factors. Volume 2, edn. Geneva: World Health Organization; 2004. p. 1851-940.

6. Pereda N, Guilera G, Forns M, Gomez-Benito J. The international epidemiology of child sexual abuse: a continuation of Finkelhor (1994) Child Abuse Negl. 2009;33(6):331-42.

7. Stoltenborgh M, van ljzendoorn M, Euser $\mathrm{E}$, Bakermans-Kranenburg M. A global perspective on child sexual abuse: meta-analysis of prevalence around the world. Child Maltreatment. 2011;16(2):79-101.

8. Barth J, Bermetz L, Heim E, Trelle S, Tonia T. The current prevalence of child sexual abuse worldwide: a systematic review and meta-analysis. Int J Public Health. 2013;58(3):469-83.

9. WHO multi-country study on women's health and domestic violence against women: summary report of initial results on prevalence health outcomes and women's responses. Geneva: World Health Organization 2005. available at: http://www.who.int/gender/violence/who_multicountry_ study/summary_report/summary_report_English2.pdf. Accessed on 08/11/2015.

10. Pereda N, Guilera G, Forns M, Gomez-Benito J. The prevalence of child sexual abuse in community and student samples: a meta-analysis. Clin Psychol Rev. 2009;29(4):328-38.

11. Ehlert U. Enduring psychobiological effects of childhood adversity. Psychoneuroendocrinology. 2013;38(9):1850-7.

12. Yampolsky L, Lev-Wiesel R, Ben-Zion I. Child sexual abuse: is it a risk factor for pregnancy? J Adv Nurs. 2010;66(9):2025-37.

13. Sorbo MF, Grimstad H, Bjorngaard JH, Schei B, Lukasse M. Prevalence of sexual, physical and emotional abuse in the Norwegian mother and child cohort study. BMC Public Health. 2013;13. doi:10.1186/1471-24581113-1186.

14. Robertson-Blackmore E, Putnam F, Rubinow D, Matthieu M, Hunn J, Putnam K, et al. Antecedent trauma exposure and risk of depression in the perinatal period. J Clin Psychiatry. 2013;74(10):942-8. 
15. Lukasse M, Vangen S, Øian P, Kumle M, Ryding E, Schei B. Childhood abuse and fear of childbirth - a population-based study. Birth. 2010;37(4):267-74.

16. Cammack A, Buss C, Entringer S, Hogue C, Hobel C, Wadhwa P. The association between early life adversity and bacterial vaginosis during pregnancy. Am J Obstet Gynecol. 2011;204(5):431.e431-8.

17. Eide J, Hovengen R, Nordhagen R. Childhood abuse and later worries about the baby's health in pregnancy. Acta Obstet Gynecol Scand. 2010;89(12):1523-31.

18. Nelson D, Lepore S. The role of stress, depression, and violence on unintended pregnancy among young urban women. J Womens Health. 2013;22(8):673-80

19. Schei B, Lukasse M, Ryding E, Campbell J, Karro H, Kristjansdottir H, et al. A history of abuse and operative delivery - results from a European multicountry cohort study. PLoS One. 2014;9(1):e87579.

20. Dunkle KL, Jewkes RK, Brown HC, Yoshihama M, Gray GE, Mclntyre JA, et al. Prevalence and patterns of gender-based violence and revictimization among women attending antenatal clinics in Soweto, South Africa. Am J Epidemiol. 2004;160(3):230-9.

21. Hutchinson GA, Jameson EM. Prevalence and risk factors for HIV infection in pregnant women in north Trinidad. West Indian Med J. 2006;55(5):346-50.

22. Audi CA, Segall-Correa AM, Santiago SM, Andrade Mda G, Perez-Escamila R. Violence against pregnant women: prevalence and associated factors. Rev Saude Publica. 2008;42(5):877-85.

23. Dinwiddie S, Heath A, Dunne M, Bucholz K, Madden P, Slutske W, et al. Early sexual abuse and lifetime psychopathology: a co-twin-control study. Psychol Med. 2000;30(1):41-52.

24. Kendler K, Bulik C, Silberg J, Hettema J, Myers J, Prescott C. Childhood sexual abuse and adult psychiatric and substance use disorders in women: an epidemiological and cotwin control analysis. Arch Gen Psychiat. 2000;57(10):953-9.

25. Chartier M, Walker J, Naimark B. Health risk behaviors and mental health problems as mediators of the relationship between childhood abuse and adult health. Am J Public Health. 2009;99(5):847-54

26. Easton SD, Renner LM, O'Leary P. Suicide attempts among men with histories of child sexual abuse: examining abuse severity, mental health, and masculine norms. Child Abuse Negl. 2013;37(6):380-7.

27. Henrichs KL, McCauley HL, Miller E, Styne DM, Saito N, Breslau J. Early menarche and childhood adversities in a nationally representative sample. Int J Pediatr Endocrinol. 2014, 2014;(1). doi:10.1186/1687-9856-2014-1114.

28. Boynton-Jarrett R, Wright RJ, Putnam FW, Lividoti Hibert E, Michels KB, Forman MR, et al. Childhood abuse and age at menarche. J Adolesc Health. 2013;52(2):241-7.

29. Noll JG, Shenk CE, Putnam KT. Childhood sexual abuse and adolescent pregnancy: a meta-analytic update. J Pediatr Psychol. 2009;34(4):366-78.

30. Leeners B, Rath W, Block E, Gorres G, Tschudin S. Risk factors for unfavorable pregnancy outcome in women with adverse childhood experiences. J Perinat Med. 2014;42(2):171-8.

31. Seng JS, Sperlich M, Low LK. Mental health, demographic, and risk behavior profiles of pregnant survivors of childhood and adult abuse. J Midwifery Womens Health. 2008;53(6):511-21.

32. Grimstad H, Schei B. Pregnancy and delivery for women with a history of child sexual abuse. Child Abuse Negl. 1999;23(1):81-90.

33. McCormick M, Litt J, Smith V, Zupancic J. Prematurity: an overview and public health implications. Annu Rev Public Health. 2011;32(1):367-79.

34. March of Dimes, PMNCH, Save the Children, WHO. Born too soon : the global action report on preterm birth. In: Howson CP, Kinney MV, Lawn JE, editors. Geneva: 2012:1-126. available at: http://www.who.int/pmnch/ media/news/2012/introduction.pdf, accessed on 08/11/2015.

35. Baba S, Wikstrom AK, Stephansson O, Cnattingius S. Influence of smoking and snuff cessation on risk of preterm birth. Eur J Epidemiol. 2012;27(4):297-304.

36. Schaaf JM, Hof MH, Mol BW, Abu-Hanna A, Ravelli AC. Recurrence risk of preterm birth in subsequent twin pregnancy after preterm singleton delivery. BJOG. 2012;119(13):1624-9.

37. Noble A, Ning Y, Woelk GB, Mahomed K, Williams MA. Preterm delivery risk in relation to maternal HIV infection, history of malaria and other infections among urban Zimbabwean women. Cent Afr J Med. 2005;51(5-6):53-8.

38. Bilano VL, Ota E, Ganchimeg T, Mori R, Souza JP. Risk factors of preeclampsia/eclampsia and its adverse outcomes in low- and middle-income countries: a WHO secondary analysis. PLoS One. 2014;9(3):e91198.

39. Cnattingius S, Villamor E, Johansson S, Edstedt Bonamy AK, Persson M, Wikstrom AK, et al. Maternal obesity and risk of preterm delivery. JAMA. 2013;309(22):2362-70.
40. Yonkers K, Smith MV, Forray A, Epperson CN, Costello D, Lin H, et al Pregnant women with posttraumatic stress disorder and risk of preterm birth. JAMA Psychiatry. 2014;71(8):897-904.

41. Sanchez SE, Puente GC, Atencio G, Qiu C, Yanez D, Gelaye B, et al. Risk of spontaneous preterm birth in relation to maternal depressive, anxiety, and stress symptoms. J Reprod Med. 2013;58(1-2):25-33.

42. Calderon-Margalit R, Qiu C, Ornoy A, Siscovick DS, Williams MA. Risk of preterm delivery and other adverse perinatal outcomes in relation to maternal use of psychotropic medications during pregnancy. Am J Obstet Gynecol. 2009;201(6):579 e571-578.

43. Sanchez SE, Alva AV, Diez Chang G, Qiu C, Yanez D, Gelaye B, et al. Risk of spontaneous preterm birth in relation to maternal exposure to intimate partner violence during pregnancy in Peru. Matern Child Health J. 2013;17(3):485-92.

44. Martin J, Hamilton B, Osterman M, Curtin S, Mathews T. Births: Final Data for 2012. Vol. 62. Hyattsville: Department of Health and Human Services, Centers for Disease Control and Prevention, National Center for Health Statistics, National Vital Statistics System; 2013. p. 1-87.

45. Institute of Medicine (IOM). Preterm Birth: Causes, Consequences, and Prevention. In: National Research Council (NRC), editor. National Academies Press: Washington DC; 2007

46. Fawke J, Lum S, Kirkby J, Hennessy E, Marlow N, Rowell V, et al. Lung function and respiratory symptoms at 11 years in children born extremely preterm: the EPICure study. Am J Respir Crit Care Med. 2010;182(2):237-45.

47. Kajantie E, Osmond C, Barker DJ, Eriksson JG. Preterm birth - a risk factor for type 2 diabetes? The Helsinki birth cohort study. Diabetes Care. 2010;33(12):2623-5.

48. Smith GD, Sterne J, Tynelius P, Lawlor DA, Rasmussen F. Birth weight of offspring and subsequent cardiovascular mortality of the parents. Epidemiology (Cambridge, Mass). 2005;16(4):563-9.

49. Robbins CL, Hutchings Y, Dietz PM, Kuklina EV, Callaghan WM. History of preterm birth and subsequent cardiovascular disease: a systematic review. Am J Obstet Gynecol. 2013;210(4):285-97.

50. Catov JM, Wu CS, Olsen J, Sutton-Tyrrell K, Li J, Nohr EA. Early or recurrent preterm birth and maternal cardiovascular disease risk. Ann Epidemiol. 2010:20(8):604-9.

51. Horan D, Hill L, Schulkin J. Childhood sexual abuse and preterm labor in adulthood: an endocrinological hypothesis. Womens Health Issues. 2000;10(1):27-33.

52. Stevens-Simon C, McAnarney E. Childhood victimization: relationship to adolescent pregnancy outcome. Child Abuse Negl. 1994;18(7):569-75.

53. Noll J, Schulkin J, Penelope T, Susman E, Breech L, Putnam F. Differential pathways to preterm delivery for sexually abused and comparison women. J Pediatr Psychol. 2007;32(10):1238-48.

54. Leeners B, Stiller R, Block E, Görres G, Rath W. Pregnancy complications in women with childhood sexual abuse experiences. J Psychosom Res. 2010;69(5):503-10

55. Benedict M, Paine L, Paine L, Brandt D, Stallings R. The association of childhood sexual abuse with depressive symptoms during pregnancy, and selected pregnancy outcomes. Child Abuse Negl. 1999;23(7):659-70.

56. Jacobs J. Child sexual abuse victimization and later sequelae during pregnancy and childbirth. J Child Sex Abuse. 1992;1(1):111-21.

57. O'Connor T, O'Halloran D, Shanahan F. The stress response and the hypothalamic-pituitary-adrenal axis: from molecule to melancholia. QJM. 2000;93(6):323-33.

58. Mastorakos G, Ilias I. Maternal and fetal hypothalamic-pituitary-adrenal axes during pregnancy and postpartum. Ann N Y Acad Sci. 2003;997:136-49.

59. Wintour E, Bell R, Carson R, Maclsaac R, Tregear G, Vale W, et al. Effect of long-term infusion of ovine corticotrophin-releasing factor in the immature ovine fetus. J Endocrinol. 1986;111(3):469-75.

60. Chan E, Falconer J, Madsen G, Rice K, Webster E, Chrousos G, et al. A corticotropin-releasing hormone type I receptor antagonist delays parturition in sheep. Endocrinology. 1998;139(7):3357-60.

61. Korebrits C, Ramirez M, Watson L, Brinkman E, Bocking A, Challis J. Maternal corticotropin-releasing hormone is increased with impending preterm birth. J Clin Endocrinol Metab. 1998:83(5):1585-91.

62. Stamatelou F, Deligeoroglou E, Farmakides G, Creatsas G. Abnormal progesterone and corticotropin releasing hormone levels are associated with preterm labour. Ann Acad Med Singapore. 2009;38(11):1011-6.

63. Wadhwa P, Garite T, Porto M, Glynn L, Chicz-DeMet A, Dunkel-Schetter C, et al. Placental corticotropin-releasing hormone $(\mathrm{CRH})$, spontaneous preterm 
birth, and fetal growth restriction: a prospective investigation. Am J Obstet Gynecol. 2004;191(4):1063-9.

64. McLean M, Smith R. Corticotropin-releasing hormone in human pregnancy and parturition. Trends Endocrin Met. 1999;10(5):174-8,

65. Grimstad H, Backe B, Jacobsen G, Schei B. Abuse history and health risk behaviors in pregnancy. Acta Obstet Gynecol Scand. 1998;77(9):893-7.

Submit your next manuscript to BioMed Central and take full advantage of:

- Convenient online submission

- Thorough peer review

- No space constraints or color figure charges

- Immediate publication on acceptance

- Inclusion in PubMed, CAS, Scopus and Google Scholar

- Research which is freely available for redistribution 